Kinestetik : Jurnal Ilmiah Pendidikan Jasmani 5 (2) (2021)

Kinestetik : Jurnal Ilmiah Pendidikan Jasmani

https://ejournal.unib.ac.id/index.php/kinestetik/index DOI : 10.33369/jk.v5i2.16525

\title{
CARDIOVASCULAR ENDURANCE LEVEL OF PHYSICAL EDUCATION STUDENTS AT TANJUNGPURA UNIVERSITY
}

\section{Fitriana Puspa Hidasari ${ }^{1 *}$}

${ }^{1}$ Physical Education Program, Teaching Training and Education Faculty, Universitas Tanjungpura, Indonesia

\section{Article Info}

Article History :

Received : June 2021

Revised : June 2021

Accepted : June 2021

Available online : June 2021

Keywords:

Cardiovascular, endurance,

\section{Abstract}

Restrictions on social activities to online learning processes increase the potential for low body movements or sedentary life in Physical Education Students (PES). The purpose of this study was to determine the level of physical fitness of Tanjungpura University Physical Education students in terms of cardiorespiratory endurance. This study used a survey method. The data collection technique uses tests and measurements with the Multistage Fitness Test (MFT) instrument. The sample in this study were 33 male students. The data analysis technique used descriptive percentage. The results showed that none of the students had VO2Max at a very good level, there were $12.5 \%$ in the good category, and most of the students with a percentage of $62.5 \%$ were at a moderate level. While the remaining $18.75 \%$ and $9.37 \%$ are at the level of less and less. The conclusion of this study is that most Physical Education Students (PES) still have good physical fitness, while some students who are at a low level and very less need to be given motivation and understanding regarding the importance of fitness in sports students. 


\section{INTRODUCTION}

Human Resources (HR) is an asset for the state (Zawawi \& Burstiando, 2020). Maintaining personal health will have a positive impact on oneself and the nation. To realize a complete human resources, good habits are needed. One of them is a healthy and active lifestyle that can provide opportunities for humans to improve their health levels (Harahap et al., 2020) and physical activity related with fitness (Hui et al., 2020). Although the current pandemic situation requires restrictions in all forms of social activity, health is something that must be maximized, especially for productive age groups such as students. Healthy and fit are basic needs so that humans can live normally, having good physical fitness can support humans in studying, studying, and other activities that support independence (Maulina \& Husna, 2018). Many studies report decreased physical activity and increases sedentary lifestyle (Stockwell et al., 2021). Health is also related to fitness, theoretically defined as a multidimensional construct containing components of cardiorespiratory endurance, muscle strength, muscle endurance, flexibility and body composition (Britton et al., 2020). Cardiorespiratory fitness is an expression of the capacity of the pulmonary and circulatori system can be assessed through measurement of maximal oxygen consumtion (VO2Max), VO2Max is the highest possible rate of oxygen consumtion during a physically intense whole-body activity, and an important factor for many types of physical performance (Björkman et al., 2021).

This research is specifically aimed at Physical Education students. One of the direct impacts of the coronavirus disease-19 pandemic for Physical Education students is the cessation of field practice lectures. In fact, dynamic health elements are needed to support lecture activities, which are mostly dominated by psychomotor aspects (skills).

This condition certainly has the potential to reduce active living habits in sports students. The decrease in the frequency and intensity of physical activity in students during 2020 is allegedly going to affect their fitness, for this reason it is important to do this research in order to get a specific picture of the fitness level of physical education students. The purpose of this study was to determine the level of physical fitness of Tanjungpura University Physical Education students in terms of cardiorespiratory endurance. There are several tests that can be used to determine a person's fitness status, one of which is the Multistage Fitness Test (MFT) (Arikan et al., 2015). The MFT is used to collect data regarding oxygen consumption during physical activity and can be used to measure maximal functional ability during the person's test. Through the Multistage Fitness Test (MFT) it can be known VO2Max (maximum oxygen volume) based on a person's level of physical activity (Sinurat, 2019). VO2Max is defined as the maximum capacity of oxygen used by 
the body during physical exercise (Syahid, 2018). VO2Max can be affected by age, gender, and physical fitness (Festiawan et al., 2020). VO2Max can also be referred to as maximal aerobic power or maximum aerobic capacity, a high maximum aerobic capacity is needed to support the body's ability (Suhdy, 2018).

\section{METHODS}

This study uses a survey method. The data collection technique uses tests and measurements with the Multistage Fitness Test (MFT) instrument, the MFT was chosen based on the consideration of several criteria based on the statement (Lavrencak et al., 2011) namely: the test method should be accurate, can be done independently, the results (response) is fast, safe, non-invasive, easy to use, and inexpensive. The sample in this study were 33 male students. The data analysis technique uses descriptive percentages presented in tables equipped with diagrams to make it easier for readers to receive information on research results.

\section{Participants}

The sample in this study were 33 male college students who are not sick and have normal body temperature.

\section{Sampling Procedures}

Sampling technique using purposive sampling. This technique was chosen because it is suitable for the purpose of the study, the number is appropriate to the current situation, and the homogeneity of gender is a specific consideration.

\section{Materials and Apparatus}

The materials using test form used to write down the achievement of the sample. Speaker used to make it easier for samples to listen to the rhythm. MFT audio used to mark beat rhythm and test level.

\section{Procedures}

Fisrt:. Prepare the field for the test. Second, divide the sample in pairs. Third, explain how to do the test and put a mark on the score. Fourth, collecting and tabulating the data. Fifth, interpretation of data through tables and diagram.

\section{Design or Data Analysis}

This study uses a survey method. The data collection technique uses tests and measurements with the Multistage Fitness Test (MFT) instrument, the MFT was chosen based on the consideration of several criteria based on the statement (Lavrencak et al., 2011) namely: the test method should be accurate, can be done independently, the results (response) is fast, safe, non-invasive, easy to use, and inexpensive. The sample in this study were 33 male students. The data analysis technique uses descriptive percentages presented in tables equipped with diagrams to make it easier for readers to receive information on research results. 


\section{RESULT}

Data collection was carried out at the Sport Science campus, FKIP Tanjungpura University. The test was carried out in the morning with the standard health protocol for the prevention of COVID-19. At the time of the study the number of complete samples was 33 students, based on measurements using a thermogun, all samples were in good health with a body temperature range of $36.00 \mathrm{C}-36.80 \mathrm{C}$. The research results are presented in the tables and diagrams below;from tables into text and give lengthy and unnecessary explanations of the Tables and Figures.

\section{Tables \& Figures}

The research data are presented in the tables and diagrams below:

Table 1. Distribution of VO2Max scores for Physical Education Students

\begin{tabular}{cccc}
\hline Scores & Percent & F & Category \\
\hline$<28$ & 9,375 & 3 & Very Less \\
\hline $28,1 \mathrm{~s} / \mathrm{d} 34$ & 18,75 & 6 & Less \\
\hline $34,1 \mathrm{~s} / \mathrm{d} 42$ & 62,5 & 20 & Enough \\
\hline $42,1 \mathrm{~s} / \mathrm{d} 52$ & 12,5 & 4 & Good \\
$52,1>$ & 0 & 0 & Very Good \\
\hline
\end{tabular}

The table above provides information about the acquisition of VO2Max scores for Physical Education students at Tanjungpura University. Based on the data presented, it can be seen that none of the students had VO2Max at a very good level, there were 4 students who were in the good category, and most of the students with a total of 20 students were at the moderate level, while the remaining 6 students and 3 students were in the middle level. less and less level. The data above provides a landscape of physical fitness conditions for Physical Education students at Tanjungpura University during the implementation of online learning (in the network).

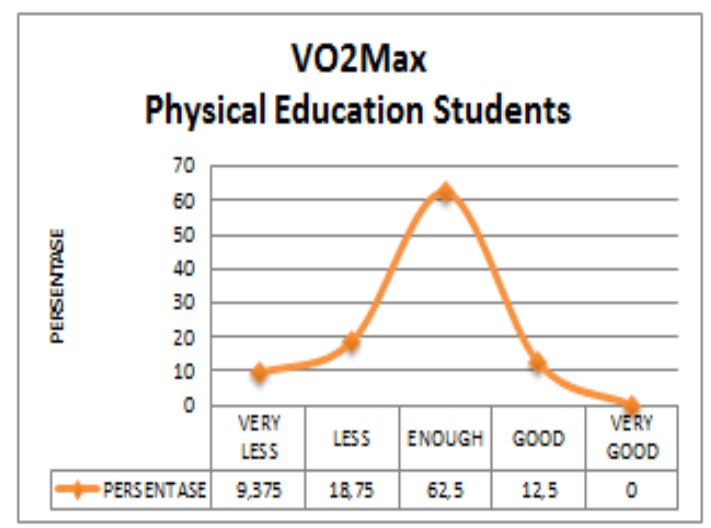

Fig 1. Graphic of PES VO2Max Level

The diagram above provides information about the acquisition of VO2Max scores for Physical Education students at Tanjungpura University. Based on the data presented, it can be seen that none of the students had a VO2Max at a very good level, $12.5 \%$ were in the good category, and most of the students with a percentage of $62.5 \%$ were at a moderate level. While the remaining $18.75 \%$ and $9.37 \%$ are at the level of less and less. The data above provides a landscape of physical fitness conditions for Physical Education students at Tanjungpura University during the implementation of online learning (in the network).

\section{DISCUSSION}

In general, most of the students still have good fitness, but some students who have lower VO2max need attention. There are several factors that are thought to affect the results of student physical fitness, including the cessation of 
practical lecture activities for two semesters, lack of awareness of maintaining fitness conditions, and low body movement or known as sedentary life. The three causal factors stated above refer to one conclusion, namely physical activity. Physical activity is one of the determinants of physical fitness (Maulina \& Husna, 2018). According to (Wang et al., 2013) to improve the physical performance of adolescents cannot be instant, we need an appropriate approach and sufficient time. Results based on research of (Kusuma, 2019) provide suggest to Tabata Training is suitable for increasing VO2Max in the moderate catergory of fitness group. The statement is relevant to the results shown in this study, that most physical education students at Tanjungpura University fall into the moderate category of fitness. Cardiorespiratory as the ability of the respiratory system to suply oxygen during active working muscles (Krivokapic, D. et al., 2014). To support physical performance, it is recommended to consume mineral water instead of energy drinks because other ingredients found in energy drinks have not been shown to have significant impact on performance (Peveler et al., 2017). it is highly recommended to return to sports that can support distance such as tennis, badminton, swimming, and golf (Löllgen et al., 2020)

\section{CONCLUSION}

Most of the Physical Education students still have good physical fitness, while some students who are at a low and very low level need to be given motivation and understanding regarding the importance of fitness in sports students. Students need for health promotion for physical education students so that they can keep themselves fit in their productive age (Hibbert et al., 2021)

\section{ACKNOWLEDGEMENT}

Thank you to all participants in this study, leaders of study programs, dean of faculties, and Rector Universitas Tanjungpura.

\section{REFERENCES}

Arikan, H., Yatar, İ., Calik-Kutukcu, E., Aribas, Z., Saglam, M., Vardar-Yagli, N., Savci, S., Inal-Ince, D., Ozcelik, U., \& Kiper, N. (2015). A comparison of respiratory and peripheral muscle strength, functional exercise capacity, activities of daily living and physical fitness in patients with cystic fibrosis and healthy subjects. Research in Developmental Disabilities, 45-46, 147-156.

https://doi.org/10.1016/j.ridd.2015.07.0 20

Björkman, F., Ekblom, O., Eklblom-Bak, E., \& Bohman, T. (2021). The Ability of a Submaximal Cycle Ergometer Test to Detect Longitudinal Changes in VO2Max. Europe PMC, 1-16. https://doi.org/10.21203/rs.3.rs580769/v1

Britton, Ú., Issartel, J., Fahey, G., Conyngham, G., \& Belton, S. (2020). What is health-related fitness? Investigating the underlying factor structure of fitness in youth. European Physical Education Review, 26(4), 782796.

https://doi.org/10.1177/1356336X1988 2060 
Festiawan, R., Suharjana, S., Priyambada, G., \& Febrianta, Y. (2020). High intensity interval training dan fartlek training: Pengaruhnya terhadap tingkat VO2 Max. Jurnal Keolahragaan, 8(1), 9-20. https://doi.org/10.21831/jk.v8i1.31076

Harahap, N. S., Sunarno, A., Simatupang, N., \& Suprayitno. (2020). The Effect of Red Dragon Fruit Juice Towards Cholesterol Level and Maximum Aerobic Capacity (VO2max) on Sport Science Students Treated with Heavy Physical Exercise. Journal of Physics: Conference Series, 1462(1). https://doi.org/10.1088/17426596/1462/1/012030

Hibbert, J. E., Klawiter, D. P., Schubert, M. M., Nessler, J. A., \& Asakawa, D. S. (2021). Strength, Cardiovascular Fitness, and Blood Lipid Measures in Law Enforcement Personnel After a 12Week Health Promotion Program. Journal of Strength and Conditioning Research.

https://doi.org/10.1519/JSC.000000000 0004081

Hui, S. S.-C., Zhang, R., Suzuki, K., Naito, H., Balasekaran, G., Song, J.-K., Park, S. Y., Liou, Y.-M., Lu, D., Poh, B. K., Kijboonchoo, K., \& Thasanasuwan, W. (2020). Physical activity and healthrelated fitness in Asian adolescents: The Asia-fit study. Journal of Sports Sciences, $\quad 38(3), \quad 273-279$. https://doi.org/10.1080/02640414.2019. 1695334

Krivokapic, D., Radulovic, B., \& Krivokapic, O. (2014). Subjective and objective estimation of the level of physical education in service of conserving health status improvement. Sport Mont, XII(4041-42), 209-2016. http://www.sportmont.ucg.ac.me/?sekci $\mathrm{j} a=$ article \& $\operatorname{artid}=198$

Kusuma, I. D. M. A. W. (2019). The influence of the differences within the preliminary vo2max level on the Tabata training results. Jurnal SPORTIF: Jurnal Penelitian Pembelajaran, 5(2), 327. https://doi.org/10.29407/js_unpgri.v5i2. 13490

Lavrencak, K., Skof, B., \& Milic, R. (2011). Stroke Volume Dinamics In Males With Different Fitness Level. Sport Mont,
$9(28, \quad 29, \quad 30), \quad 224-230$. http://www.sportmont.ucg.ac.me/clanci/ SportMont_Avg_2011_Lavrencak_224230.pdf

Löllgen, H., Bachl, N., Papadopoulou, T., Shafik, A., Holloway, G., Vonbank, K., Jones, N. E., Bigard, X., Niederseer, D., Meyer, J., Muniz-Pardos, B., Debruyne, A., Zupet, P., Steinacker, J. M., Wolfarth, B., Bilzon, J. L. J., Ionescu, A., Dohi, M., Swart, J., ... Pitsiladis, Y. P. (2020). Recommendations for return to sport during the SARS-CoV-2 pandemic. BMJ Open Sport \& Exercise Medicine, 6(1), e000858. https://doi.org/10.1136/bmjsem-2020000858

Maulina, N., \& Husna, C. A. (2018). Penilaian Indeks Kebugaran Jasmani Pada Mahasiswa Program Studi Pendidikan Dokter Angkatan 2015 Dengan Metode Harvard Step Up Test. AVERROUS: Jurnal Kedokteran Dan Kesehatan Malikussaleh, $3(2), \quad 72$. https://doi.org/10.29103/averrous.v3i2. 443

Peveler, W. W., Sanders, G. J., Marczinski, C. A., \& Holmer, B. (2017). Effects of Energy Drinks on Economy and Cardiovascular Measures. Journal of Strength and Conditioning Research, 31(4), 882-887. https://doi.org/10.1519/JSC.000000000 0001553

Sinurat, R. (2019). Profil Tingkat Volume Oksigen Maskimal (VO2 Maks) Pada Atlet Sepakbola Universitas Pasir Pengaraian. Jurnal SPORTIF: Jurnal Penelitian Pembelajaran, 5(1), 80-88. https://ojs.unpkediri.ac.id/index.php/pjk /article/view/12801

Stockwell, S., Trott, M., Tully, M., Shin, J., Barnett, Y., Butler, L., McDermott, D., Schuch, F., \& Smith, L. (2021). Changes in physical activity and sedentary behaviours from before to during the COVID-19 pandemic lockdown: a systematic review. BMJ Open Sport \& Exercise Medicine, 7(1), e000960. https://doi.org/10.1136/bmjsem-2020000960

Suhdy, M. (2018). Pengaruh Metode Latihan Interval Intensif dan Interval Ekstensif 
terhadap Peningkatan VO2 Max.

Gelanggang Olahraga: Jurnal

Pendidikan Jasmani Dan Olahraga

(JPJO), 1(2), 1-10.

https://doi.org/10.31539/jpjo.v1i2.130

Syahid, A. M. (2018). Analysis of VO2Max

Differences between Laboratory Test

and Field Test in Rowing. Pendidikan Jasmani Olahraga, 3(1), 122-128. https://doi.org/10.17509/jpjo.v6i1.3030 1

Wang, C. K. J., Pyun, D. Y., Liu, W. C., Lim, B. S. C., \& Li, F. (2013). Longitudinal changes in physical fitness performance in youth. European Physical Education Review, 19(3), 329-346. https://doi.org/10.1177/1356336X1349 5630

Zawawi, M. A., \& Burstiando, R. (2020). Profil kondisi fisik atlet senior Wushu Sanda Kediri dalam menghadapi Pekan Olahraga Provinsi (Porprov) Jawa Timur tahun 2019. Jurnal SPORTIF: Jurnal Penelitian Pembelajaran, 6(1), 259-271.

https://doi.org/10.29407/js_unpgri.v6i1. 14279 